\title{
PERLINDUNGAN HUKUM TERHADAP KONSUMEN ATAS PRODUK OBRAL DENGAN IKLAN TANPA INFORMASI YANG JELAS
}

\author{
Oleh: \\ Muhammad Yasid ${ }^{1)}$, \\ Nanci Yosepin Simbolon ${ }^{2)}$ \\ Boy Chasea Pasi ${ }^{3)}$, \\ dan Ricky Pratama Siregar ${ }^{4)}$ \\ Universitas Darma Agung, Medan 1,2,3,4) \\ Email: \\ yasidfakultashukum@gmail.com ${ }^{1)}$ \\ $\underline{\text { nancisimbolon123@gmail.com }}^{2)}$ \\ jhonricky98@ gmail.com ${ }^{3)}$ \\ $\underline{\text { boikaseapasi22@gmail.com }}^{4)}$
}

\begin{abstract}
The existence of a product that is sold on sale can benefit parties, (the businessperson and the consumer). However, the existence of hidden conditions in the sale of products sold on these sales, is clearly very detrimental to consumers. In order to be more attractive to consumers in buying sale products, businesses use advertising facilities but unfortunately, most of these advertisements contain information that is not clear, thus violating the rights of consumers, which in the end, consumers also suffer losses. The results of this study indicate that advertisements without clear information on sale products violate the provisions in Law Number 8 of 1999 concerning Consumer Protection, regulated in Article 11 where business actors in the case of sales made through sale or auction are prohibited from deceiving / misleading consumers by: stating goods as if they meet certain quality standards; does not contain hidden defects; not intending to sell the goods offered but with the intention to sell other goods; does not provide goods in certain quantities and / or sufficient quantities with the intention of selling other goods; and raise prices or tariffs of goods before making a sale. The responsibility of business actors in advertising product sales without clear information is to provide compensation to consumers in the form of refunds or replacement of goods (products) of the same type or equivalent in value to losses suffered by consumers.
\end{abstract}

Keywords: Advertising, Consumer

\begin{abstract}
ABSTRAK
Adanya produk yang dijual secara obral dapat menguntungkan kedua belah pihak, (pihak pelaku usaha dan pihak konsumen). Akan tetapi, adanya syarat tersembunyi dalam penjualan produk yang dijual secara obral tersebut, jelas sangat merugikan konsumen. Untuk dapat lebih menarik minat konsumen dalam membeli produk obral, maka pelaku usaha menggunakan sarana iklan. Namun sayangnya, sebagian besar dari iklan tersebut berisi informasi yang tidak jelas, sehingga melanggar hak-hak konsumen, yang pada akhirnya, konsumen juga yang menderita kerugian. Hasil penelitian ini menunjukkan bahwa Iklan tanpa disertai informasi yang jelas terhadap produk obral melanggar ketentuan dalam Undang-Undang Nomor 8 Tahun 1999 tentang
\end{abstract}


Perlindungan Konsumen, diatur pada Pasal 11 dimana Pelaku usaha dalam hal penjualan yang dilakukan melalui cara obral atau lelang, dilarang mengelabui/menyesatkan konsumen dengan: menyatakan barang seolah olah telah memenuhi standar mutu tertentu; tidak mengandung cacat tersembunyi; tidak berniat untuk menjual barang yang ditawarkan melainkan dengan maksud untuk menjual barang lain; tidak menyediakan barang dalam jumlah tertentu dan/atau jumlah yang cukup dengan maksud menjual barang yang lain; dan menaikkan harga atau tarif barang sebelum melakukan obral. Tanggung jawab pelaku usaha dalam mengiklankan produk obral tanpa informasi yang jelas adalah dengan memberikan ganti rugi kepada konsumen berupa pengembalian uang atau penggantian barang (produk) yang sejenis ataupun yang setara nilainya terhadap kerugian yang dialami konsumen.

\section{Kata Kunci : Iklan, Konsumen.}

\section{PENDAHULUAN}

Pembangunan perekonomian nasional pada era globalisasi harus dapat mendukung tumbuhnya dunia usaha sehingga mampu menghasilkan beraneka barang yang memiliki kandungan teknologi yang dapat meningkatkan kesejahteraan masyarakat banyak sekaligus mendapatkan kepastian atas barang yang diperoleh dari perdagangan tanpa mengakibatkan kerugian konsumen. Untuk meningkatkan harkat dan martabat konsumen perlu meningkatkan kesadaran, pengetahuan, kepedulian, kemampuan dan kemandirian konsumen untuk melindungi dirinya serta menumbuh kembangkan sikap pelaku usaha yang bertanggung jawab.

Semakin terbukanya pasar nasional sebagai akibat dari proses globalisasi ekonomi, perdagangan bebas maka pelaku usaha harus tetap menjamin peningkatan kesejahteraan masyarakat serta kepastian atas mutu, jumlah, dan keamanan barang yang diperoleh konsumen di pasar yang untuk dikonsumsimnya. Akibat adanya arus globalisasi tersebut maka biasanya terjadi penurunan harga atau lebih dikenal dengan diskon, atau juga dapat dikatakan sebagai penjualan produk secara obral.

Adanya produk yang dijual secara obral, disatu sisi memang menguntungkan kedua belah pihak, yaitu pihak pelaku usaha dan pihak konsumen. Akan tetapi, dengan melekatnya syarat tersembunyi dalam penjualan produk yang dijual secara obral tersebut, jelas sangat merugikan konsumen. Bahkan sebenarnya, dengan hanya datang ke tempat penawaran produk itu, konsumen sudah mengalami kerugian dalam hal waktu, tenaga, pikiran dan biaya transportasi. Untuk dapat lebih menarik minat konsumen dalam membeli produk obral, maka pelaku usaha menggunakan sarana iklan. Namun sayangnya, sebagian besar dari iklan tersebut berisi informasi yang tidak jelas, sehingga melanggar hak-hak konsumen, yang pada akhirnya, konsumen juga yang menderita kerugian.

Berdasarkan uraian tersebut di atas, terdapat permasalahan yang perlu pemahaman lebih lanjut, yaitu :

1. Bagaimana iklan tanpa disertai informasi yang jelas terhadap produk obral melanggar ketentuan dalam Undang-Undang Nomor 8 Tahun 1999 tentang Perlindungan Konsumen ?

2. Bagaimana tanggung jawab pelaku usaha dalam mengiklankan produk obral tanpa informasi yang jelas mengakibatkan kerugian konsumen ?

3. Bagaimana penyelesaian sengketa antara konsumen dengan pelaku usaha yang mengiklankan produk obral tanpa informasi yang jelas? 


\section{TINJAUAN PUSTAKA}

Tinjaun pustaka merupakan pengertian-pengertian terhadap apa yang hendak diteliti dalam hal ini yang berkaitan dengan perlindungan hukum bagi konsumen atas tanpa informasi yang jelas terhadap produk obral, yang sedapat mungkin ditelusuri dari perundangundangan, dan juga pemahaman mengenai perlindungan konsumen sedapat mungkin referensinya diambil dari berbagai buku-buku tentang hukum konsumen. Oleh karenanya berdasarkan Undang Undang Nomor 8 Tahun 1999 tentang Perlindungan Konsumen memberikan definisi yang relevan dengan penelitian ini sebagai berikut:

1. Konsumen adalah setiap orang pemakai barang dan/atau jasa yang tersedia dalam masyarakat, baik bagi kepentingan diri sendiri, keluarga, orang lain, maupun makhluk hidup lain dan tidak untuk diperdagangkan. (Pasal 1 angka 2).

2. Perlindungan konsumen adalah segala upaya yang menjamin adanya kepastian hukum untuk memberi perlindungan kepada konsumen. Pasal 1 angka 1 ).

3. Pelaku usaha adalah setiap orang perseorangan atau badan usaha, baik yang berbentuk badan hukum maupun bukan badan hukum yang didirikan dan berkedudukan atau melakukan kegiatan dalam wilayah hukum negara Indonesia, baik sendiri maupun bersama-sama melalui perjanjian menyelenggarakan kegiatan usaha dalam berbagai bidang ekonomi. (Pasal 1 angka 3).

4. Barang adalah setiap benda baik berwujud maupun tidak berwujud, baik bergerak maupun tidak bergerak, dapat dihabiskan maupun tidak dapat dihabiskan, yang dapat untuk diperdagangkan, dipakai, dipergunakan, atau dimanfaatkan oleh konsumen. (Pasal 1 angka 4).
5. Jasa adalah setiap layanan yang berbentuk pekerjaan atau prestasi yang disediakan bagi masyarakat untuk dimanfaatkan oleh konsumen. (Pasal 1 angka 5).

6. Promosi adalah kegiatan pengenalan atau penyebarluasan informasi suatu barang dan/atau jasa untuk menarik minat beli konsumen terhadap barang dan/atau jasa yang akan dan sedang diperdagangkan. (Pasal 1 angka 6).

\section{METODE PELAKSANAAN}

Metode pelaksanaan ataupun meteode penelitian hukum dilaksanakan dengan pendektan yuridis normatif, menggunakan data sekunder bersumber dari bahan hukum primer, bahan hukum sekunder dan bahan hukum tersier. Data diperoleh dari studi kepustakaan. Setelah data terkumpul dilakukan analisis dengan metode deskriptif kualitatif.

\section{HASIL DAN PEMBAHASAN}

\section{A. Iklan Tanpa Disertai Informasi Yang Jelas Terhadap Produk Obral Melanggar Ketentuan Dalam Undang Undang Perlindungan Konsumen}

Iklan merupakan suatu bentuk komunikasi untuk mempromosikan sesuatu hal, dengan menggunakan media massa. Dengan adanya iklan, maka diharapkan informasi yang tercantum didalamnya dapat tersampaikan dengan baik. Menurut Shidarta, tujuan utama iklan adalah untuk meningkatkan penjualan barang dan/ atau jasa yang ditawarkan.

Fungsi iklan merupakan sebagai penawaran. Hal ini dapat diartikan bahwa iklan tersebut berusaha menawarkan produk dengan cara mempengaruhi konsumen sedemikian rupa untuk mau membeli atau menggunakan produk yang diiklankan. 
Mempengaruhi konsumen merupakan salah satu dari strategi pemasaran yang harus dilakukan oleh pelaku usaha dalam rangka untuk meningkatkan penjualan sekaligus meningkatkan laba perusahaan. Akan tetapi, meskipun memberikan pengaruh kepada konsumen, pelaku usaha harus tetap memperbolehkan konsumen untuk menentukan pilihannya sendiri. Tidak diperbolehkan mempengaruhi sedemikian rupa sampai konsumen merasa terpaksa dan terdesak sehingga tidak mempunyai pilihan lain. Terkait dengan adanya paksaan dalam memberikan pengaruh ini, ketentuan dalam Pasal 15 Undang Undang Nomor 8 Tahun 1999 tentang Perlindungan Konsumen, dapat dijadikan suatu pedoman, menyatakan bahwa: Pelaku usaha dalam menawarkan barang dan/atau jasa dilarang melakukan dengan cara pemaksaan atau cara lain yang dapat menimbulkan gangguan baik fisik maupun psikis terhadap konsumen.

Pelaku usaha dalam usaha untuk mempengaruhi konsumen, biasanya memberikan semacam janji-janji tanpa memberikan informasi yang jelas. Akan tetapi hasil yang didapat oleh setiap orang belum pasti sama dari janji-janji hal ini melanggar ketentuan pada Pasal 9 ayat (1) huruf k Undang-Undang No. 8 Tahun 1999 tentang Perlindungan Konsumen, yang menyatakan bahwa : Pelaku usaha dilarang menawarkan, mempromosikan, mengiklankan suatu barang dan/atau jasa secara tidak benar, dan/atau seolah-olah menawarkan sesuatu yang mengandung janji yang belum pasti.

Pemberian janji melalui iklan juga perlu diperhatikan untuk tidak sampai merendahkan produk lain yang sejenis, misalnya saja membandingkan produk lain yang sejenis dengan mengungkapkan kelemahan atau kekurangan produk tersebut dan mengungkapkan kelebihan atau keunggulan produk yang diiklankan karena hal ini dilarang sesuai dengan Pasal 9 ayat (1) huruf i Undang Undang Nomor 8 Tahun 1999 tentang Perlindungan Konsumen, menyatakan bahwa : Pelaku usaha dilarang menawarkan, mempromosikan, mengiklankan suatu barang dan/atau jasa secara tidak benar, dan/atau seolah-olah secara langsung atau tidak langsung merendahkan barang dan/atau jasa lain.

Adanya informasi produk melalui iklan, yang jelas dan lengkap akan sangat membantu konsumen dalam menentukan pilihan atas suatu produk yang dipasarkan. Salah satu penyampaian informasi produk tersebut adalah melalui iklan. Dengan semakin membanjirnya aneka produk yang ada dipasaran, sehingga kebutuhan akan informasi suatu produk lebih banyak dipenuhi oleh adanya iklan. Pelaku usaha masih menganggap iklan merupakan cara paling efektif dan efisien dalam memberikan informasi produk kepada konsumen. Namun yang cukup disayangkan, banyak dari iklan tersebut yang berisi informasi yang tidak jelas dan lebih mengutamakan untuk memberikan pengaruh bagi konsumen agar membeli produk obral yang diiklankan.

Untuk dapat memberikan perlindungan hukum bagi konsumen atas adanya tindakan pelaku usaha yang merugikan konsumen, dalam hal ini iklan tanpa informasi yang jelas (menyesatkan), maka pemerintah Republik Indonesia memberlakukan Undang-Undang Nomor 8 Tahun 1999 tentang Perlindungan Konsumen. Salah satu bentuk upaya perlindungan bagi konsumen yang tercantum dalam undang-undang tersebut adalah adanya penyebutan secara tegas hak-hak konsumen.

Hak adalah kepentingan yang dilindungi hukum, sedangkan 
kepentingan adalah tuntutan perorangan atau kelompok yang diharapkan untuk dipenuhi. Pada dasarnya, hak itu ada karena 3 (tiga) hal, yakni sebagai berikut:

1. Hak itu ada karena merupakan kodrat manusia sebagai makhluk ciptaan Tuhan Yang Maha Esa. Sebagai makhluk ciptaan Tuhan, manusia mempunyai hak sebagai manusia dan mempertahankan kemanusiaannya, misalnya hak untuk hidup, hak untuk memperoleh pendidikan, hak untuk bekerja, dan lain sebagainya. Hak ini lazimnya disebut sebagai hak asasi.

2. Hak itu ada karena merupakan pemberian hukum negara kepada manusia dalam kedudukannya sebagai warga negara. Misalnya, hak untuk mendirikan bangunan, hak untuk mengendarai kendaraan bermotor, dan lain sebagainya.

3. Hak itu ada karena adanya hubungan hukum antara seseorang dan orang lain melalui sebuah perjanjian. Misalnya, seseorang meminjamkan suatu barang miliknya kepada orang lain, maka orang lain itu mempunyai hak pakai atas barang tersebut.

Dengan uraian yang telah dikemukakan di atas, maka dapat dipahami pula bahwa hak-hak konsumen itu memiliki kandungan antara lain : hak konsumen sebagai manusia yang perlu memenuhi kebutuhannya untuk hidup, hak konsumen sebagai subjek hukum dan warga negara yang berpedoman pada peraturan perundang-undangan, dan hak konsumen sebagai pihak-pihak dalam mengadakan perjanjian dengan pelaku usaha.

\section{B. Tanggung Jawab Pelaku Usaha Dalam Mengiklankan Produk Tanpa Informasi Yang Jelas}

\section{Mengakibatkan Konsumen}

Menurut J. H. Nieuwenhus, kerugian adalah berkurangnya harta kekayaan pihak yang satu, yang disebabkan oleh perbuatan (melakukan atau membiarkan) yang melanggar norma oleh pihak lain.

Jika suatu peristiwa yang merugikan konsumen telah terjadi, misalnya timbul kerugian karena memakai atau mengonsumsi suatu produk, yang pertama sekali dicari adalah apakah ada hubungan kontraktual antara pelaku usaha dan konsumen. Bila ditemukan ada hubungan kontraktual antara pelaku usaha dan konsumen, langkah berikutnya mencari bagianbagian dari kontrak/perjanjian yang mungkin tidak dipenuhi sehingga menimbulkan kerugian pada konsumen.

Pelaku usaha mempunyai tugas dan kewajiban untuk ikut serta menciptakan dan menjaga iklim usaha yang sehat yang menunjang bagi pembangunan perekonomian nasional secara keseluruhan. Karena itu, kepada pelaku usaha dibebankan tanggung jawab atas pelaksanaan tugas dan kewajiban itu, yaitu melalui penerapan norma-norma hukum, kepatutan, dan menjunjung tinggi kebiasaan yang berlaku dikalangan dunia usaha.

Bentuk pertanggungjawaban administratif yang dapat dituntut dari produsen sebagai pelaku usaha diatur di dalam Pasal 60 Undang-Undang Nomor 8 Tahun 1999 tentang Perlindungan Konsumen, yaitu pembayaran ganti kerugian paling banyak $\mathrm{Rp}$. 200.000.000,00 (dua ratus juta) rupiah, terhadap pelanggaran atas ketentuan tentang:

a. Kelalaian membayar ganti rugi kepada konsumen (Pasal 19 ayat (2) dan ayat (3);

b. Periklanan yang tidak memenuhi syarat (Pasal 20); 
c. Kelalaian dalam menyediakan suku cadang (Pasal 25); dan

d. Kelalaian memenuhi garansi/jaminan yang dijanjikan.

Sedangkan pertanggungjawaban pidana yang dibebankan kepada produsen, baik pelaku usaha yang bersangkutan maupun pengurusnya (jika produsen berbentuk badan usaha) adalah:

a. Pidana penjara paling lama lima tahun atas pelanggaran terhadap ketentuan Pasal 8; Pasal 9; Pasal 10; Pasal 13 ayat (2); Pasal 15; Pasal 17 ayat (1) huruf a, huruf $b$, huruf c, dan huruf e, ayat (2); dan Pasal 18.

b. Pidana penjara paling lama dua tahun atau denda paling banyak $\mathrm{Rp}$ 500.000:000,00 (lima ratus juta) rupiah, terhadap pelanggaran atas ketentuan Pasal 11, Pasal 12, Pasal 13 ayat (1), Pasal 14, Pasal 16, dan Pasal 17 ayat (1) huruf d dan huruf f.

c. Terhadap sanksi pidana diatas dapat dikenakan hukuman tambahan berupa tindakan:

1) perampasan barang tertentu;

2) pengumuman keputusan hakim;

3) pembayaran ganti rugi;

4) perintah penghentian kegiatan tertentu yang menyebabkan timbulnya kerugian konsumen;

5) kewajiban menarik barang dari peredaran; atau

6) pencabutan izin usaha.

Menurut Pasal 1365 KUH

Perdata, tiap-tiap perbuatan melawan hukum, yang membawa kerugian kepada orang lain, mewajibkan orang yang karena salahnya menerbitkan kerugian itu, mengganti kerugian tersebut. Kemudian, dalam Pasal 1367 KUH Perdata diatur mengenai pertanggungjawaban khusus sehubungan dengan perbuatan melawan hukum, yaitu pertanggungjawaban atas barang sebagai berikut: seseorang tidak saja bertanggung jawab untuk kerugian yang disebabkan perbuatannya sendiri, tetapi juga untuk kerugian yang disebabkan perbuatan orang orang yang menjadi tanggungannya atau disebabkan oleh barang-barang yang berada di bawah pengawasannya.

\section{Penyelesaian Sengketa Antara Konsumen Dengan Pelaku Usaha Yang Mengiklankan Produk Tanpa Informasi Yang Jelas}

Undang-Undang Perlindungan Konsumen memberi dua macam ruang untuk penyelesaian sengketa konsumen, yaitu penyelesaian sengketa konsumen melalui pengadilan dan penyelesaian konsumen di luar pengadilan. Hal ini termuat pada Pasal 45, yang berbunyi:

(1)Setiap konsumen yang dirugikan dapat menggugat pelaku usaha melalui lembaga yang bertugas menyelesaikan sengketa antara konsumen dan pelaku usaha atau melalui peradilan yang berada di lingkungan peradilan umum.

(2)Penyelesaian sengketa konsumen dapat ditempuh melalui pengadilan atau diluar pengadilan berdasarkan pilihan sukarela para pihak yang bersengketa.

(3)Penyelesaian sengketa di luar pengadilan sebagaimana dimaksud pada ayat (2) tidak menghilangkan tanggungjawab pidana sebagaimana diatur dalam Undang-undang.

(4)Apabila telah dipilih upaya penyelesaian sengketa konsumen diluar pengadilan, gugatan melalui pengadilan hanya dapat ditempuh apabila upaya tersebut dinyatakan tidak berhasil oleh salah satu pihak atau oleh para pihak yang bersengketa.

Sebenarnya penyelesaian sengketa diluar pengadilan baru diketahui melalui Pasal 47, sedangkan Pasal 45 justru menyebut lembaga 
khusus sebagai penyelesaian di luar pengadilan. Pasal 47 yang berbunyi:

Penyelesaian sengketa konsumen di luar pengadilan diselenggarakan untuk mencapai kesepakatan mengenai bentuk dan besarnya ganti rugi dan/atau mengenai tindakan tertentu untuk menjamin tidak akan terjadi kembali atau tidak akan terulang kembali kerugian yang diderita oleh konsumen.

Mengikuti ketentuan Pasal 45 ayat (1) jo. Pasal 47 Undang-Undang Perlindungan Konsumen tersebut, penyelesaian sengketa konsumen diluar pengadilan dapat ditempuh dengan dua cara, yaitu:

1. Penyelesaian tuntutan ganti kerugian seketika; dan

2. Penyelesaian tuntutan ganti kerugian melalui BPSK.

Dengan demikian, terbuka tiga cara untuk menyelesaikan sengketa konsumen, yaitu:

1. Penyelesaian sengketa konsumen melalui pengadilan;

2. Penyelesaian sengketa konsumen dengan tuntutan seketika; dan

3. Penyelesaian sengketa konsumen melalui Badan Penyelesaian Sengketa Konsumen (BPSK).

Satu dari ketiga cara itu dapat ditempuh oleh pihak-pihak yang bersengketa, dengan ketentuan bahwa penyelesaian sengketa melalui tuntutan seketika wajib ditempuh pertama kali untuk memperoleh kesepakatan para pihak. Sedangkan dua cara lainnya adalah pilihan yang ditempuh setelah penyelesaian dengan cara kesepakatan gagal. Kalau sudah menempuh cara melalui pengadilan tidak dapat lagi ditempuh penyelesaian melalui BPSK dan sebaliknya.

Konsumen yang dirugikan karena memakai atau mengonsumsi produk yang cacat hanya akan mendapat penggantian kerugian apabila meng- ajukan permintaan atau tuntutan atas hal tersebut. Permintaan atau penuntutan penggantian kerugian ini mutlak dilakukan oleh orang yang merasa berhak untuk mendapatkannya. Tidak akan ada penggantian kerugian selain karena dimohonkan terlebih dahulu ke pengadilan dengan syarat-syarat tertentu.

\section{SIMPULAN}

Adapun simpulan dalam penelitian ini sebagai berikut:

1. Iklan tanpa disertai informasi yang jelas terhadap produk obral melanggar ketentuan dalam Undang-Undang Nomor 8 Tahun 1999 tentang Perlindungan Konsumen, sebagaimana yang diatur pada Pasal 11 dimana Pelaku usaha dalam hal penjualan yang dilakukan melalui cara obral atau lelang, dilarang mengelabui/ menyesatkan konsumen dengan: menyatakan barang seolah olah telah memenuhi standar mutu tertentu; tidak mengandung cacat tersembunyi; tidak berniat untuk menjual barang yang ditawarkan melainkan dengan maksud untuk menjual barang lain; tidak menyediakan barang dalam jumlah tertentu dan/atau jumlah yang cukup dengan maksud menjual barang yang lain; dan menaikkan harga atau tarif barang sebelum melakukan obral.

2. Tanggung jawab pelaku usaha dalam mengiklankan produk obral tanpa informasi yang jelas mengakibatkan kerugian konsumen adalah dengan memberikan ganti rugi kepada konsumen berupa pengembalian uang atau penggantian barang (produk) yang sejenis ataupun yang setara nilainya terhadap kerugian yang dialami konsumen hal ini sebagaimana yang diamanhkan pada Pasal 19 Undang-Undang Nomor 8 Tahun 1999 tentang Perlindungan Konsumen. 
3. Penyelesaian sengketa antara konsumen dengan pelaku usaha yang mengiklankan produk obral tanpa informasi yang jelas adalah dengan cara penyelesaian melalui Pengadilan dengan mengajukan gugatan kepada pelaku usaha, dan juga penyelesaian diluar Pengadilan, yang diselenggarakan untuk mencapai kesepakatan mengenai bentuk dan besarnya ganti rugi dan/atau mengenai tindakan tertentu untuk menjamin tidak akan terjadi kembali atau tidak akan terulang kembali kerugian yang diderita oleh konsumen akibat membeli produk obral. Sebagiaman yang diamanahkan pada Pasal 45 Undang Undang Nomor 8 Tahun 1999 tentang Perlindungan Konsumen.

\section{DAFTAR PUSTAKA}

Amiruddin dan Zainal Asikin., Pengantar Metode Penelitian Hukum, Rajawali Pers, Jakarta: 2012.

Darus Badrulzaman, Mariam, $K U H$ Perdata Buku III Hukum Perikatan Dengan Penjelasan, Alumni, Bandung: 1993.

Dunne, J. M. van dan Gregor v. d. Burght, terjemahan L. S. Pusponegoro, Perbuatan Melawan Hukum, Dewan Kerja Sama Ilmu Hukum Indonesia-Belanda, Jakarta: 1987.

Koentjoroningrat, Metode-Metode Penelitian Masyarakat, Gramedia Pustaka Utama, Jakarta: 1997.

Kotler, Philip, Manajemen Pemasaran: Analisis, Perencanaan dan Penegndalian, Erlangga, Jakarta: 1994.

Mertokusumo, Sudikno, Mengenal Hukum (Suatu Pengantar), Liberty, Yogyakarta, 1999.
Hukum Acara Perdata Indonesia, Liberty, Yogyakarta: 1988.

Miru, Ahmadi, dan Sutarman Yudo, Hukum Perlindungan Konsumen, Rajawali Press, Jakarta: 2004.

Nieuwenhuis, J.H., Pokok-Pokok Hukum Perikatan, terjemahan Djasadin Saragih, Universitas Airlangga, Surabaya, 1985.

Prodjodikoro, Wirjono, Perbuatan Melanggar Hukum, Sumur, Bandung: 1990.

Siahaan, N.H.T., Hukum Konsumen: Perlindungan Konsumen dan Tanggung Jawab Produk, Panta Rei, Jakarta: 2005.

Sidabolak, Janus, Hukum Perlindungan Konsumen di Indonesia, Citra Aditya Bakti, Bandung: 2010.

Simatupang, Taufik H., Aspek Hukum Periklanan dalam Perspektif Perlindungan Konsumen, Citra Aditya Bakti, Bandung, 2004.

Shidarta, Pengetahuan Tentang Aspek Hukum Perlindungan Konsumen dan Status Sosial Media Cetak serta Perlindungan Hak-hak Konsumen dalam Iklan, Universitas Gadjah Mada, Yogyakarta: 1994.

Soekanto, Soerjono, Ringkasan Metodologi Penelitian Hukum Empiris, Indonesia Hillco, Jakarta: 1990.

Sofwan Assauri, Manajemen Pemasaran, Dasar, Konsep dan Strategi, Rajawali Press, Jakarta: 1990.

Subekti, Hukum Perjanjian, Intermasa, Jakarta: 2002.

Sunggono, Bambang, Metode Penelitian Hukum (Suatu Pengantar), Raja Grafindo Persada, Jakarta: 2001. 
Susanto, Happy, Hak-Hak Konsumen Jika Dirugikan, Visimedia, Jakarta : 2008 .

Sutantion, Retnowulan, dan Oeripkartawinata, Iskandar, Hukum Acara Perdata Dalam Teori dan Praktek, Alumni, Bandung: 2002.

Toar, Agnes M., Tanggung Jawab Produk, Sejarah dan Perkembangannya di Beberapa Negara, Ujung Padang, Belanda Indonesia: 1988.

Tim Penyusun Kamus Pusat Pembinaan dan Pengembangan Bahasa, Kamus Besar Bahasa Indonesia, Balai Pustaka, Jakarta: 1994.

Waluyo, Bambang, Penelitian Hukum dalam Praktek, Sinar Grafika, Jakarta: 1996.

Nasution, Bismar, Metode Penelitian Hukum Normatif dan
Perbandingan Hukum, Makalah, Fakultas Hukum USU, Medan: 18 Februari 2003.

Putro, Deniyanto Perlindungan Hukum Bagi Konsumen Atas Penjualan Produk Obral, Skripsi, Fakultas Hukum Airlangga, Surabaya: 2009.

Purwadi, Ari, Sistem Tanggung Jawab Periklanan pada Perlindungan Konsumen, Yuridika, Fakultas Hukum Universitas Airlangga, Surabaya, Vol. 16, No. 5, September 2001.

Kitab Undang Hukum Perdata (Burgelijk Wetbook)

Undang-Undang Republik Indonesia Nomor 8 Tahun 1999 tentang Perlindungan Konsumen.

Undang-Undang Republik Indonesia Nomor 18 Tahun 2012 tentang Pangan. 